\title{
Serving the Cities: An Indian Scenario
}

\author{
Dr. Purobi Sharma
}

\begin{abstract}
Urbanization process has its impacts leading to many issues. Provision for services is the most important response to these issues. It determines the quality of life in the cities. It is a major component of urban policies. At present the challenges of creating urban infrastructure have been recognized as: providing services in mega cities which are major centers of economic activities; infrastructure in small and medium towns; role of government versus private agencies; the question of financing; growth of inclusive cities and sustainability in providing urban infrastructure and above all the application of technical knowledge and expertise in determination of level of needs and implementation of policies. In developing countries the rate of urbanization is much higher than the urban preparedness. The study of urban picture in India is the narration of these issues. The present paper makes a modest attempt to depict it.
\end{abstract}

Key words: urban development; strategy; finance; norms; politicization.

\section{Introduction}

. The issues related to policy perspective of urban development cover a very wide range from poverty eradication to role of cities as centers of economic opportunities. The study of urban situation in a country gives the idea of policy framework, strategies and realities of the situation. In ultimate analysis, urban development process in highly responsive to its socio-economic context. It is a common knowledge that lack of planning perspective at regional and sub-regional levels may lead to concentration of population and economic activities in certain areas and stagnation in some others. .

Urban policy framework in India necessarily leads to the economic and demographic considerations. A huge urban land shortage artificially created by out modeled planning and consequent problems of housing shortages and growth of slums, chaotic transport, unequal municipal finances and governance, untidy informal irregular growth, huge infrastructure shortages, water logging and poor quality of health and sanitation are some of the challenges before urban planning in India.

The urban planning system currently in vogue needs to be restructured to make it inclusive with a strategic vision, to ensure the integration of physical and socioeconomic planning, transportation and land use planning, and to promote participation by the people in the planning and development processes in the light of the 74th Constitution Amendment Act, 1992 envisioning democratic decentralization and power to the people. This should be a key vehicle for achieving the objectives of the 12th Plan - faster and more inclusive economic growth.

The urban planning process must combine spatial planning with socio-economic and financial planning; and transportation planning with land use and environmental planning to be more responsive to the changing needs and demands of the citizens. Urban planning in India is a state subject and under the $12^{\text {th }}$ Schedule of the 74th Constitution Amendment Act, the subject of urban planning, including town planning has been mandated for the third tier - Municipal Corporations and Municipalities. The subject of regional planning, however, falls in the domain of the State Governments. While the 74th Amendment Act envisages that the District and Metropolitan Planning Committees consolidate plans for the component urban and rural bodies, they send the "draft" District and Metropolitan Plans to the State Government. The implication is that these plans are to be integrated with the State Plans. As per the Constitutional mandate, the District and Metropolitan Development Plans have to ensure coordinated spatial planning, sharing of natural and other resources, integrated provision of infrastructure and environmental conservation. These are the areas which require guidelines so as to synchronies bottom-up and top-down approval. The measures in reality are the indicators of Top Down method of urban development management.

The recent 2011 census has placed India's urban population as 377 million persons being 31.16 per cent of total population of the country. Successive census results since independence reveal a steady growth in urban population from 17.3 per cent of India's population in 1951 to 31.16 per cent in 2011. Polarization of population in higher order urban settlements is a conspicuous feature of urban development in India. There is a consistent higher growth trend of class I and class II cities in comparison to smaller towns. According to Population Census 1991 the 300 class I cities contributed $65.20 \%$ of the total urban population of the country and more than $50 \%$ of this population lived in 23 metropolitan areas. The rest $35 \%$ was distributed over other smaller towns. The large cities have shown a consistently higher growth rate in comparison to the smaller urban 
areas. During 1981-91 the growth of smaller towns was 34.5\% whereas class I cities accounted for $46.87 \%$ as decadal growth rate. In 2001, the number of class I cities grew to 394 and in the recent 2011 census study, it has been recorded to have increased to 468 , accounting for about 264.9 million, i.e. $70 \%$ of the total urban population. The number of towns has also increased largely i.e. 5161 in 2001 and 7935 in 2011. Since 1951 India has witnessed high strides in its urban growth in metropolitan cities which account for one-third of country's urban population. The four mega cities-Bombay, Calcutta, Delhi and Madras have more than 5 million population since 1991. ${ }^{[1]}$

Table : 1 Distribution of Urban Population by Million Plus and other Cities

\begin{tabular}{|l|c|c|c|c|c|c|c|c|c|}
\hline \multirow{2}{*}{$\begin{array}{l}\text { Category of } \\
\text { Cities/Towns }\end{array}$} & 2001 & 2011 & $\begin{array}{l}\text { Net } \\
\text { Increase } \\
\text { (millions) }\end{array}$ & $\begin{array}{l}\text { Percent } \\
\text { Increase }\end{array}$ & $\begin{array}{l}\text { Percent } \\
\text { share of } \\
\text { Net } \\
\text { Increase }\end{array}$ & 2001 & 2011 & $\begin{array}{l}\text { Net } \\
\text { Increase } \\
\text { (millions) }\end{array}$ & $\begin{array}{l}\text { Percent } \\
\text { Increase }\end{array}$ \\
\hline Million+ cities & 121 & 161 & 40 & 33 & 45 & 35 & 53 & 22 & 63 \\
\hline $\begin{array}{l}\text { Other cities and } \\
\text { Towns }\end{array}$ & 166 & 216 & 50 & 30 & 55 & 5126 & 7882 & 2756 & 54 \\
\hline $\begin{array}{l}\text { Total urban } \\
\text { population/No } \\
\text { of Towns }\end{array}$ & 207 & 377 & 90 & 31 & 100 & 5161 & 7935 & 2774 & 54 \\
\hline
\end{tabular}

Source : Census of India, 2001 and 2011.

\section{Political Intervention}

In the developing societies, development management authorities find it difficult to maintain the pace with urban development in terms of demographic and spatial connotations while making provisions for the urban infrastructure. The Planning Commission expressed the view long back that the positive role of urbanization is often overshadowed by the lack of sufficient provisions for urban infrastructure and therefore the challenge of reorienting the urbanization process lies in overcoming the infrastructure; deficiencies ${ }^{[2]}$. There is tremendous pressure on civic infrastructure systems including water supply, sewerage and drainage, uncollected solid waste, parks and open spaces, transport, etc. It has also led to deterioration in the quality of city environments. In several cities, the problems of traffic congestion, pollution, poverty, inadequate housing, crime, and social unrest are assuming alarming proportions.

According to the Eleventh Five Year Plan Document, the extent and magnitude of the urban population calls for extra efforts by city planners and managers to cope up with the ever-growing strain on the urban infrastructure. Special attention is needed for management and governance of urban areas which are at present fragmented between different State-level agencies and urban local bodies with lack of co-ordination.

The urbanization policy puts greater emphasis on the development of infrastructural facilities in small, medium and intermediate towns so that these could attain the status of growth centers in rural hinterland. The poor condition of infrastructure put severe strain and stress on urban life and activities in India, the issue leads to many vital questions such as rationalization of norms and standards for urban infrastructure; techniques for provision, delivery, operation and maintenance; tapping of non-traditional sources and proper management of traditional sources for funding etc. Therefore urban infrastructure issues form a major part of policy and strategy of urban development. It is also the part of the supportive system which leads to various stages of urban development in an area determining the quality of urban life. It has been observed that the physical infrastructure facilities like - water supply, drainage, sewerage, water disposal system, transportation, power can determine the contribution of a city to the national economy and lack of social infrastructure facilities such as education health, telecommunication, security, fire-fighting services, socio-cultural activities, recreation, parks, banks and financial institutions, housing and other services have adverse impact on quality of life in urban areas. Traditionally the provision of infrastructures have remained within the domain of governments and the involvement of private sector has been gradually encouraged by the Planning Commission, the Task Force, the N.C.U. other relevant advisory bodies.

Cities are finding it increasingly difficult to provide and maintain infrastructures due to enormous increase in the rate of growth of population which does not allow bridging the gap between the demand and supply of infrastructure, creates over dependence upon fiscal resources starved public sector for infrastructure provision, politicized decision making and lack of co-ordination on the part of various departments involved in providing these services. The fact that infrastructure services do not pay for themselves and the government does not have resources and financial capacity to subsidize the beneficiaries had resulted in low availability of funds. With increasing requirement this has led to the deficiency in volumes as well as quality of services ${ }^{[3]}$.

Since independence planning and management of urban infrastructure has been tackled by various government agencies at the national and state level and in many cases international co-operation has been sought for and obtained from organizations like World Bank, Asian Development Bank ${ }^{[4]}$. Such a system of 
management has not been adequate in the light of changed socio-economic and political circumstances. At the same time, existence of multiple agencies has led to a confusing situation in which responsibilities have never been defined and demarcated in a fruitful way. The political situation at various governmental levels also creates confusion in the decision making process. It has been observed that in the present planning system, the highincome group has greater accessibility to urban infrastructure with growing involvement of international financial institutions leading to high tariffs and trimming of subsidies ${ }^{[5]}$. Though the case for privatization of services has been raised, no clear policy to determine the extent of involvement of private sector has been formulated and the nature of collective benefits has not been assessed. All these result into suffering of the poor in big cities.

In the provision of Urban Infrastructure, multiple authorities have jurisdiction over different aspects of the same infrastructure facility. At times the same service may have multiple authorities having jurisdiction over it. In light of the multiple agencies involved, most urban infrastructure projects are conceived as separate projects without due planning or impact assessment on how to best derive or gain efficiencies from such projects. The simplest example of this is the perennial digging of city roads by various agencies to lay utility infrastructure. The same road could, at different times within a short span of time, be excavated upon by telephone utility providers, city gas distribution providers, sewerage utility, water supply utility, public transport corporation and electricity utility as a result of which stretches of city roads may not be available for large section of time continuously.

Similarly, a relevant urban infrastructure project needs approval for the implementation depending on the city, from different authorities: of the municipality, the urban town and country planning department, a development authority, State Government public works department, state government irrigation department, city police, city fire department and the State Government itself.

\section{Status of Urban Infrastructure}

In India, the first attempt at setting urban service norms and standards was made in 1963 by the Zakaria Committee, which laid down the physical norms and corresponding expenditure norms for five services, i.e. water supply, sewerage, storm water drainage, urban roads and street lighting. The Zakaria Committee adopted a demand-driven approach for estimating service standards and per capita investment requirements for urban India. The standards were derived from the actual data collected on the quantum of basic urban services, demand for services, cost of provision, maintenance of services and municipal finances from a sample of cities of different sizes. For example, the standards for per capita water consumption were estimated to range between 45 and 270 liters per day depending on city size.

Subsequently, other government agencies/institutions like the Town and Country Planning Organisation (1974), Planning Commission (1983, 1999), Operation Research Group (1989), Ministry of Urban Development, Government of India (1991), Central Public Health and Environmental Engineering Organisation (1999), and state governments have come up with norms for different services. The Zakaria Committee's financial norms adjusted for inflation are still widely used as benchmarks for assessing infrastructure needs in urban areas, even though they are outdated and do not measure up to the standards relevant for an economy growing at 8 to 9 percent per annum ${ }^{[6]}$. The pattern of consumption of urban services has changed significantly over time as a result of increase in income and technological advances. Rising aspiration in a rapidly growing economy also call for a new look at the norms for public service delivery.

The March 2011, Report on Indian Urban Infrastructure and Services reviews the current state of urban service delivery in India and reveals the negligent state of service delivery to four factors that are discussed below. The Report also recommends new service delivery norms and standards for urban areas in India.

\section{Water supply}

As per Census 2011, Drinking Water within the premises is available to $71.2 \%$ of the urban population vis-à-vis $65.4 \%$ as per Census 2001. Similarly, 20.7\% of the population has access to Drinking Water near the premises vide Census 2011 vis a vis $25.2 \%$ vide Census 2001. None of the cities have 24x7 water supply. Nonrevenue water, which includes leakages of various kinds, is fairly high, being in the range of 40 to 50 percent.

\section{Sanitation}

The challenge of sanitation in Indian cities is acute. In fact the problem of lack of systematic sanitation facility is much worse in urban areas than in rural areas. A Sanitation rating of 423 class-I cities done in 2009-10 by Ministry of Urban Development, GoI revealed that only 39 cities qualified on 3 basic water quality parameters of turbidity, residual chlorine and Thermo Tolerant Coliform bacteria. According to Census 2011, $32.7 \%$ of the urban population has access to a piped sewer system and $12.6 \%$ of the urban population still defecates in the open. Installed sewage treatment capacity is only $30 \%$ as per Central Pollution Control. Board 
Report 2009 . The capacity utilization is around $72.2 \%$, which means that only about $20 \%$ of sewage generated is treated before disposal in most of the cities and towns.

\section{Solid Waste Management}

The management and disposal of solid waste generated in Indian cities is a major problem. According to the CPCB Report 2005, about 1,15,000 MT of municipal waste is generated daily. Collection performance varies from city to city. Staff deployed to manage SWM is also fairly low as per requirements. In most of the cities, waste is transported and dumped to land fill sites. Scientific treatment and disposal of solid waste is practically non-existent.

\section{Urban Transport}

Public transport accounts for only 22 percent of urban transport in India, compared with 49 percent in lower middle-income countries (e.g. the Philippines, Venezuela, Egypt) and 40 percent in upper middle-income countries (e.g. South Africa, South Korea, Brazil). The share of public transport is declining steadily as neither the quantity is sufficient nor the quality is satisfactory. The overall image of public transport is still quite low. As such generally only the people with no other alternatives move by public transport. Out of 423 Class I cities, only 65 have a formal city bus service as of 2012 and that too owing to the intervention of the Central Government intervention through the programme of funding of buses for city transport. In 2006, this number was only 20 cities $^{\left[{ }^{[7]}\right.}$

Table: 2 Salient Statistics of the State of Urban Service Delivery in India, 2011

\begin{tabular}{|c|c|}
\hline Service & Salient Statistics \\
\hline \multirow[t]{3}{*}{ Water Supply } & $\begin{array}{l}64 \text { per cent of urban population is covered by individual connections and stand posts in India. (91 per cent } \\
\text { in China, } 86 \text { per cent in South Africa and } 80 \text { per cent in Brazil) }\end{array}$ \\
\hline & $\begin{array}{l}\text { Duration of water supply in Indian cities ranges from } 1 \text { hour to } 6 \text { hours, compared with } 24 \text { hours in Brazil } \\
\text { and China and } 22 \text { hours in Vietnam. }\end{array}$ \\
\hline & $\begin{array}{l}\text { Water utilities in India are typically able to recover only } 30-35 \text { per cent of the operations and management } \\
(\mathrm{O} \& \mathrm{M}) \text { cost. In the Philippines and Cambodia, most water utilities recover the full O\&M cost. Even in } \\
\text { Bangladesh, water utilities recover about } 64 \text { per cent of their O\&M cost }\end{array}$ \\
\hline \multirow[t]{3}{*}{ Sewerage and Sanitation } & 4861 out of the 5161 cities/towns in India do not have even a partial sewerage network. \\
\hline & $\begin{array}{l}\text { About } 18 \text { per cent of urban households do not have access to any form of latrine facility and defecate in the } \\
\text { open. }\end{array}$ \\
\hline & Only 21 per cent of the waste water generated is treated, compared with57 per cent in South Africa. \\
\hline \multirow[t]{2}{*}{ Solid Waste Management } & $\begin{array}{l}\text { Waste collection coverage ranges from } 70 \text { per cent to } 90 \text { per cent in major metropolitan cities, and is less } \\
\text { than } 50 \text { per cent in smaller cities }\end{array}$ \\
\hline & Less than 30 per cent of the solid waste is segregated. \\
\hline \multirow[t]{3}{*}{ Urban Transport and Roads } & $\begin{array}{l}\text { Public transport accounts for only } 22 \text { per cent of urban transport compared with } 49 \text { per cent in lower middle } \\
\text { income countries (e.g. the Philippines, Venezuela, Egypt) and } 40 \text { per cent in upper middle income countries } \\
\text { (e.g. South Africa, South Korea, Brazil) }\end{array}$ \\
\hline & $\begin{array}{l}\text { Share of the public transport fleet in India has decreased sharply from } 11 \text { per cent in } 1951 \text { to } 1.1 \text { per cent in } \\
2001 \text {. }\end{array}$ \\
\hline & $\begin{array}{l}\text { Road density }(\mathrm{km} / \mathrm{sq} . \mathrm{km}) \text { is } 9.2 \text { in Singapore, } 9.7 \text { in Curitiba, } 21.8 \text { in Seoul, } 10 \text { in Johannesburg, } 3.8 \text { in } \\
\text { Chennai, and } 19.2 \text { in New Delhi. }\end{array}$ \\
\hline
\end{tabular}

Source: Report on Indian Urban Infrastructure and Services, March 2011, HPEC.

A summary of service delivery standards and norms recommended by the Report are provided in Table 2 below:

Table: 2

\begin{tabular}{|c|c|c|c|}
\hline \multicolumn{4}{|c|}{ Summary of Service Norms } \\
\hline $\begin{array}{l}\text { Water } \\
\text { Supply }\end{array}$ & \multicolumn{3}{|c|}{$\begin{array}{l}\text { - } 100 \% \text { individual piped water supply for all households including informal settlement for all } \\
\text { cities } \\
\text { - } \quad \text { Continuity for supply: } 24 \times 7 \text { water supply for all cities } \\
\text { Per capita consumption norm: } 134 \text { lpcd for all cities }\end{array}$} \\
\hline Sewarage & \multicolumn{3}{|c|}{$\begin{array}{l}\text { - Underground sewerage system for all cities and } 100 \text { per cent collection and treatment of waste } \\
\text { water. }\end{array}$} \\
\hline Solid Waste & \multicolumn{3}{|c|}{$\begin{array}{l}\text { - } 100 \text { per cent of solid water collected, transported and treated for all cities as per Municipal solid } \\
\text { waste } 2000 \text { rules }\end{array}$} \\
\hline \multirow[t]{5}{*}{ Urban Roads } & City Size Class & $\begin{array}{l}\text { Area under Roads } \\
\text { (per cent) }\end{array}$ & $\begin{array}{l}\text { Road Density }(\mathrm{km} / \mathrm{sq} \text {. } \\
\mathrm{km})\end{array}$ \\
\hline & Class IA & 11 & 12.25 \\
\hline & Class IB & 11 & 12.25 \\
\hline & Class IC & 11 & 12.25 \\
\hline & Class II-IV + & 7 & 7.00 \\
\hline Storm Water & \multicolumn{3}{|c|}{ Drain network covering 100 per cent road length on both sides of the roads for all cities. } \\
\hline
\end{tabular}


Serving The Cities: An Indian Scenario

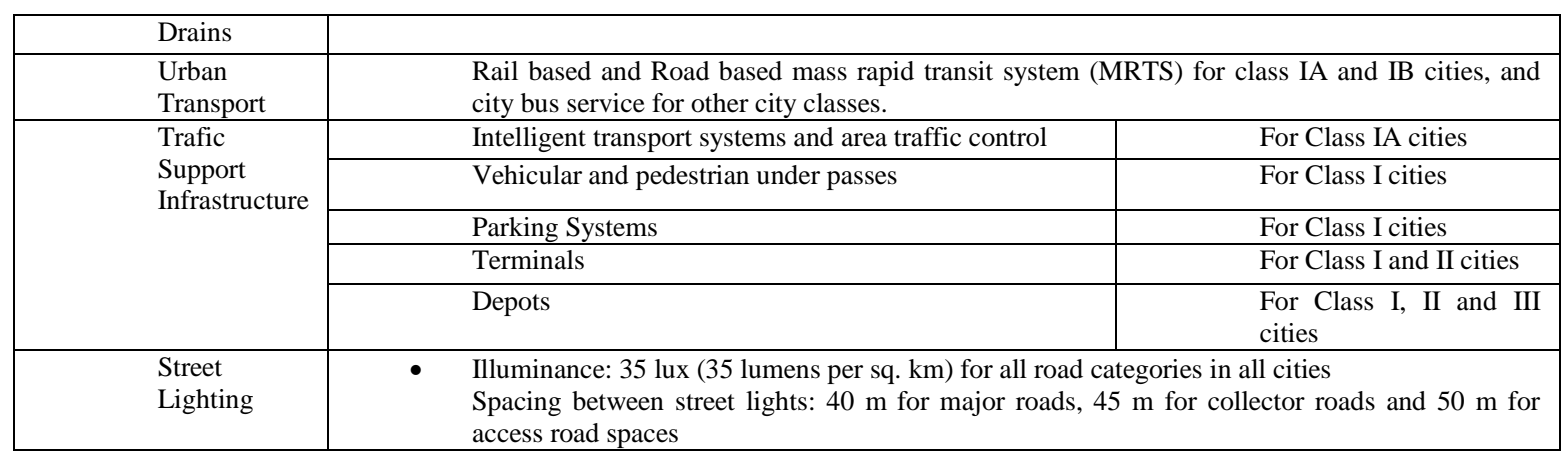

Source: Ministry of Urban Development of India, 2008 and 2009, Reports.

The current status of the urban infrastructure is absolutely not at par with the demands of the existing urban population, its up gradation and development has been repeatedly empfasized. It has been estimated that India's population may rise to about 1.7 billion by 2050 and about half a billion of urban population will need new homes. Due to the current trend of brisk rate of urbanization the capacities of the cities of the country will have to grow almost 400 percent in less than 50 years. In this context, the rationale for an aggressive and ambitious policy of affordable housing is very clear ${ }^{[8]}$.

According to the Economic Survey of India 2011, The Eleventh Five Year Plan had estimated the total fund requirement for implementation of the target for urban water supply, sewerage and sanitation, drainage, and solid waste management to be Rs. 1,29,237 crore and that for urban transport to be Rs. 1,32,590 crore. According to estimates based on the City Development Plans (CDPs) prepared by the States under the Jawaharlal Nehru National Urban Renewal Mission (JNNURM) launched in 2005-06, the requirements for both urban infrastructure services and urban transport were estimated to be as high as Rs. 8,00,000 crore.

The provision for delivery of services represents the picture of failure in bridging the striking gap between the needs and the reality throughout the years. The report on Urban Infrastructure and Services, March 2011 forwarded by High Powered Expert Committee, set up by the Ministry of Urban Development and headed by Dr. Isher Judge Ahluwalia, has projected very large investment requirements for providing public services to specified norms and also supporting the urban growth processes. The committee proposed a framework for governance and financing public services with greater involvement of urban local bodies. The report stated that urban India is visibly deficient in the quality of services they provide, even to the existing population. Current service levels are too low in a fastest growing economy of the world. The committee recommended that without reforming governance for service delivery, additional capital investments in urban infrastructure will not result in improvements in service delivery. The committee also recommended for a New Improved JNNURM as progress in implementing reforms under the present JNNURM has been slow.

\section{Financing Urban Infrastructure}

The Indian Urban Infrastructure and Service Report, 2011 estimates investment for urban infrastructure over the 20-year period from 2012 to 2031 to be Rs 39.2 lakh crore (at 2009-10 prices). It proposes a three pillar framework for financing this expenditure. One, securing the revenue base of ULBs through 'exclusive taxes' and a guaranteed and predictable share of ULBs in tax revenue of state governments. Second, a new Improved Jawaharlal Nehru National Urban Renewal Mission from the Government of India. Third, external Sources of finance: through reforms in governance and financing ULBs can begin to move away from a weak financial base towards a framework which enhances the credit worthiness of the ULBs and improves their ability to generate and leverage revenue surpluses for accessing market funds. ${ }^{[9]}$

The available funds for the maintaining and improving the basic urban infrastructure are also inadequate along with the gap in the requirement and provision of these. Traditionally the funds for financing the urban infrastructure are accumulated from the internal local bodies and loans and grants from the State Government, further supplemented by the directed credit from institutions such as HUDCO and LIC linked to State Government guarantees, and also a small component of bilateral and multilateral assistance was also available. However some weaknesses of the traditional system led to a severe back log in investments given the insufficiency of the government budgetary support. Thus the implementation of projects within this structure led to inadequate utilization of resources on account of lack of project development and poor management skills. Efficiency and environmental degradation is thus a common negative impact of the development process of towns and cities. The estimate of urban scenarios is also characterized by large regional inter-city and intra-city variations. The problem of non-accuracy in estimating realities arises because of the large scale illegal settlements which remain outside the control of the government. In such situations inadequacy of infrastructure 
create problems of dis-functioning of urban system. Urban crime, as has been reported by National Institute of Urban Affairs mostly originates in such settlements. Adverse impact of shortage and imbalances of basic urban services lead to air, water and noise pollution, increasing incidence of fire in squatter settlements in and around Indian metropolis. On an aggregate, $21 \%$ of urban population in India lives in slum and squatter settlements with extremely poor accessibility to basic services.

At state level, the local governments bear the responsibility of provision and delivery of infrastructure services. However, various state level agencies, like P.W.D., Public Health, Medical, Education etc. are also assigned with responsibility of provision and operation of service. Parastatal agencies such as Electricity Board, Water Supply and Sewerage Board, Housing Board etc. are also involved in such tasks, Local authorities are generally entrusted with the maintenance of supply of services including layout and maintenance of minor roads, leaving major link roads to P.W.D. Specialized agencies manage communication system, however in major cities the private telephone agencies are also involved in providing telecommunication services. Education, health, banking, urban transport activities are shared both by the public and private sectors. The augmentation of urban infrastructure has been materialized by some Central and state sector schemes like integrated development of small and medium towns (IDSMT) Scheme, under operation since the Sixth Five Year Plan applicable to towns or cities with population upto 5 lakhs. The Scheme is instrumental in providing some infrastructural services to Indian towns and cities, such as, strengthening of roads, site development, bus and truck terminals, construction of storm water drains, development of market complexes, tourist centres street lights, slaughter houses, parks and gardens, traffic management schemes and social amenities for the poor etc. There are also Mega City Schemes which cover cities like Hyderabad, Banglore, Calcutta, Chennai, Mumbai. The capital development schemes are meant for construction, development and improvement of capital cities of states. Delhi, Bhubaneswar, Chandigarh were sele4cted for development under such schemes. The provision for social infrastructure is also made by the public and private sectors without any clear demarcation of responsibilities. There is wide variation in the level of involvement of private individuals and institutions in providing social amenities among towns and cities of India ${ }^{[10] .}$ Thus the present approach to urban infrastructure provision is not a comprehensive one, but a piecemeal effort based on rigid sectoral planning.

Development of infrastructure is a pre-requisite of economic role of cities. Hence, the developing countries have to accord emphasis on two key components of development of infrastructure, management and financing. The World Development Report, 1994, on infrastructure stated that "services associated with the use of infrastructure (in terms of value added) account for roughly $7 \%$ to $11 \%$ of G.D.P." As the Municipal management of services represent a grim picture, it is highly necessary that the existing system is handled carefully at municipal or state and central government level. As stated earlier, the Seventh and Eight Five Year Plan documents emphasized the need of creating appropriate mechanisms for finance organization and management of infrastructure services and amenities. The same line of thinking has been reflected in subsequent National policies.

The situation of management of services is in a major flux, which urgently needs a proper political decision as well as administrative intervention to reflect the trend of urban development management thought articulated through various policy guidelines since 1980s. The financial requirement of provision for services is met by budgetary allocation to the Central, State and urban local bodies through 5 year plans and Annual Plans. Supplementary funds are obtained from L.I.C. World, Bank, multinational and bi-lateral programmes channelized through the Central and State Governments. The resources made available to state and urban local bodies as grants and loans however suffer from lack of cost recovery from beneficiaries and non-repayment of loans by operating agencies, which lead to "a vicious cycle of mounting backlog of resources for these sectors"

Institutional financing for urban infrastructure has always been very limited. Since 1988, the HUDCO started financing exclusive infrastructure schemes through its urban Infrastructure Finance Wing. The objectives of the Wing had been:

- to increase the supply of capital that is made available to local authorities to finance infrastructural projects with special reference to urban services,

- to help cities of all sizes, especially small and medium towns to provide adequate Urban services by providing long term finance for urban projects,

- to help in the channeling and monitoring of funds in a systematic manner for urban development activities through state level agencies and

- to offer technical assistance in project preparation, installation of viable local revenue structure and in adequate pricing of urban services.

These objectives have been the major contents of the recent infrastructure funding system. 


\section{The issues before development management :}

The Planning Commission focuses on the need of serious attention towards unprecedented managerial and policy challenge posed by accelerated pace of urbanization today. There has been an incomplete devolution of functions to the elected bodies as per 74th Constitutional Amendment Act, possibly because of the unwillingness of the state governments. Urban India today is distributed in shape-with a diverse range of large and small cities spread widely around the nation. India will probably continue on a path of distributed model of urbanization because this suits its federal structure and helps to ensure that migration flows aren't unbalanced toward any particular city or cities the makeup of the nation. Population and incomes increase, demand for every key service such as water, transportation and sewage treatment, low income housing will increase five- to sevenfold in cities of every size and type. And if India continues on its current path, provision of urban infrastructure will not meet the needs of a sustainable city. There has been an incomplete devolution of functions to the elected bodies as per 74th Constitutional Amendment Act, possibly because of the unwillingness of the state governments. In addition, very few Indian cities have 2030 master plans that take into account peak transportation loads, requirements for low-income affordable housing and climate change. In general, the capacity to execute the urban reforms and projects at the municipal and state level has been historically inadequate. According to Twelfth Finance Commission documents, India needs to work on several areas to manage its urbanization: The following are perhaps the most important: Inclusive cities, urban governance, funding, planning, capacity building and low-income housing India also needs to start a political process where the urban issues are debated with evolution of meaningful solutions.

The poor and lower income groups must be brought into the mainstream in cities. Regulations intended to manage densities and discourage migration both limit the supply of land and require many households to consume more land than they would choose. This drives urban sprawl and pushes up the price of land and the cost of service delivery for all. High standards for parking, coverage limits, setbacks, elevators, road widths, reservations for health centers schools etc. prevent the poor from choosing how much to consume of the costliest resource (urban land) to put a roof over their heads, and comply with legal requirements. Informality is now the only path to affordable housing for the bulk of the population in India's cities. But informality implies illegality and therefore vulnerability. While lower income groups pay dearly for shelter and services - they are bereft of normal property rights protections and their investments are thus far riskier than those of the well off. They must instead depend on the good will of bureaucrats and politicians - to safeguard their homes and places of business. These barriers to healthy urbanization come not only at a high human cost, but take a toll on productivity. Planning Commission observes that chronic informality discourages the very investments in education, health and housing improvements the lower classes need to improve their own lot and contribute more to the national economy. Meaningful reforms have been suggested to enable true devolution of power and responsibilities from the states to the local and metropolitan bodies according to the 74th Amendment Act. This is because by 2030, India's largest cities will be bigger than many countries today. India's urban governance of cities needs an over-haul. India's current urban governance is in sharp contrast to large cities elsewhere that have empowered mayors with long tenures and clear accountability for the city's performance. India also needs to clearly define the relative roles of its metropolitan and municipal structures for its 20 largest metropolitan areas. With cities growing beyond municipal boundaries, having fully formed metropolitan authorities with clearly defined roles will be essential for the successful management of large cities in India. Devolution has to be supported by more reforms in urban financing that will reduce cities' dependence on the Centre and the states and unleash internal revenue sources. Consistent with most international examples, there are several sources of funding that Indian cities could tap into, to a far greater extent than today: Monetizing land assets; higher collection of property taxes, user charges that reflect costs; debt and public-private partnerships (PPPs); and central/state government funding. However, internal funding alone will not be enough, even in large cities. A portion has to come from the central and state governments. Here one can use central schemes such as JNNURM and Rajiv Awas Yojana but eventually India needs to move towards a systematic formula rather than ad-hoc grants. For large cities with deep economies, this might mean allowing them to retain 20 percent of goods and services tax (GST) revenues. This is consistent with the 13th Central Finance Commission's assessment that GST - a consumption-based tax that creates local incentives for growth and that is therefore well suited for direct allocation to the third tier of government. For smaller cities, however, a better option would be to give guaranteed annual grants.

\section{Conclusion}

A real step-up in the capabilities and expertise of urban local bodies will be critical to devolution and improvement of service delivery. Reforms will have to address the development of professional managers for urban management functions, who are in short supply and will be required in large numbers. New innovative approaches will have to be explored to tap into the expertise available in the private and social sector. The planning Commission also states that India needs to build technical and managerial depth in its city 
administrations. In the Indian Civil Services, India has a benchmark for how to build a dedicated cadre for governance. India now needs to create an equivalent cadre for cities, as well as allow lateral entry of privatesector executives. In ultimate analysis urbanization in India is a necessary concomitant to the accelerated growth of economy, where as the urban development management system is still marked by an uncoordinated and isolated scheme of management which remained in segments.

\section{References}

[1]. Compiled from the census reports of the respective years.

[2]. Eighth Five Year Plan documents (1992-93), Chapter-13, p. 348.

[3]. J.K. Gupta, 'Urban Infrastructure Development Need for Innovation Approaches', National T. \& C.P. Congress, Bhubaneshwar, December 29-31, 1998.

[4]. N.I.U.A., 'Planning and Management of Urban Services', New Delhi, 1991, p. 49.

[5]. ibid p; 110.

[6]. K.K. Pandey Theme Paper for the 56 ${ }^{\text {th }}$ Members' Annual Conference, 2012; Administration of Urban Development and Urban Service Delivery; Indian Institute of Public Administration, New Delhi.

[7]. Report on Indian Infrastructure and Services, March 2011; Dr. Isher Judge Ahluwalia, The High Powered Expert Committee (HPEC) for Estimating the Investment Requirements for Urban Infrastructure Services.

[8]. ibid.

[9]. Source: Report on Sub-Committee on Financing urban infrastructure in $12^{\text {th }}$ plan, March 2012, Ministry of Urban Development, Govt. of India.

[10]. $\quad 47^{\text {th }}$ National T. \& C.P. Congress, op. cit., paper by Dr. S.K. Kulshrestha, Editor, Spatio-Economic Record, New Delhi and Urban and Regional Planner, I.T.P.I., No. 19..

[11]. A.K. Jain, Additional Commissioner (Planning), Delhi Development Authority, Delhi, The Challenge Financing and Management of Urban Infrastructure, paper in $47^{\text {th }}$ T. \& C.P. Congress, op. cit. No. 7. 